\title{
EFFECT OF PARTICLE SHAPE ON THE WORKABILITY AND PROPERTIES OF CONVENTIONAL BITUMINOUS MIXES
}

\author{
Shivakumara S N $\mathbf{1}^{1}$ K M Mallesh ${ }^{2}$, Mohammed Ilyas Anjum ${ }^{3}$ \\ ${ }^{1}$ Post Graduate Student, Department of Civil Engineering, Siddaganga Institute of Technology, Tumakuru, Karnataka \\ ${ }^{2}$ AssociateProfessor, Department of Civil Engineering, Siddaganga Institute of Technology, Tumakuru, Karnataka \\ ${ }^{3}$ Professor, Department of Civil Engineering, Ghousia college of engineering, Ramanagaram, Karnataka
}

\begin{abstract}
The flakiness and elongation index is an important physical property of mineral aggregates affecting the quality of asphalt mixes. The presence of Combined Flakiness and Elongation index (CFEI) exceeding certain limits adversely affects the durability and properties of asphalt mixture. A bituminous mixture is composed of approximately $95 \%$ by weight or $80 \%$ by volume of mineral aggregates. Therefore it is important to see how aggregate gradation and different combined indices affect the performance of bituminous mixes. In recent times continuous increase in volume of traffic has resulted in increased in demands for further research relating to the properties of the material such as workability and stability of hot mix asphalt. Workability of hot mix asphalt is a critical element in getting the desired density of asphalt pavements
\end{abstract}

The present study was taken up with the observations of evaluating the influence of different combined shape indices on workability of bituminous mixes at upper, middle and lower gradation as per the MORTH specified For BC-II. In this study Marshall Method of mix design is adopted and OBC is determined only 30-35\% combined indices of mid gradation. Same OBC is used for entire research work for evaluating the workability of bituminous mix at upper, middle and lower gradation of 30-35\% $35-40 \%, 40-45 \%$ and $45-50 \%$ of combined indices.

Keywords: combined indices, workability, aggregate gradation, hot mix asphalt. -****

\section{INTRODUCTION}

In India, approximately $98 \%$ roads are flexible types, probably because of economy. There are two million miles of paved roadways in India. The hot mix asphalt (HMA) is used on approximately $98 \%$ of all paved surfaces. Increasing traffic volumes, tire pressure, and Loading in recent time has place more demand on engineering roads. Technically, a well-designed and constructed road will not only support regional and national development of a country, but also assist in sustaining the life span of the infrastructure. To achieve this, an adequate mix design is essential. Asphalt concrete as one of road surface material is mainly influenced by the quality of aggregates since aggregate occupies $95 \%$ by weight in total mixture. Various shapes of aggregates might be occurred during crushing in the crushing plant starting from rounded to flaky and elongated aggregates. Some tests on aggregates have to be done prior its use in asphalt mixture such as gradation, toughness, durability, shapes, surface texture, specific gravity, etc. A high percentage of flat and elongated aggregates tend to break during mixing, handling, construction and subsequent traffic operations. Hence there was a need to study the performance of asphalt mixes for varying combined flakiness and elongation indices. Hence an attempt has been made to study the effect of combined flakiness and elongation indices on performance of asphalt concrete mixes. The engineering properties of aggregates, including shapes, size, gradation, and bitumen content are very important in having satisfied performance of asphalt concrete mixture. The flakiness and elongation indices of aggregates are important physical properties of aggregates, which affect the quality of asphalt mixes

\section{WORKABILITY}

Workability is an important element in obtaining the desired HMA smoothness and density within a compacted pavement. Workability is the property that describes the ease production, handling, placing, and compaction of asphalt mixtures with minimal energy consumption. Mixtures that are very harsh, it can be more difficult to construct smooth pavements. If not properly compacted the pavement layer, there was reduced the life of the pavement. On the other hand well compacted pavement results in longer pavement life, lower pavement maintenance. Chunwang et, al,[6] conducted and determined the production temperature of warm mix asphalt by workability test. The workability of WMA was measured by a prototype workability device. The aimed torque was adopted in measuring the workability of the mixtures with origin bitumen. The results indicated that the aimed torque range was reasonable and the production temperatures of WMA mixtures determined in this study were approximately consistent. The final performance test also indicated that Eqi-torque temperature methodology was feasible and effective. Salah Mohamed khalil et, al,[7] determine the correlation between workability and compatibility as a means for developing an index for measuring the compatibility and workability at different temperatures. 
These determines the stripping at different mixing and compaction temperatures as well as detecting any variations in the mix design in terms of bitumen content, fraction of combined aggregate before placing the mix asphalt concrete on the road. The torque is calculated using following formula.

$$
\begin{gathered}
\mathrm{T}=\frac{60 * \text { OUT PUT POWER }}{2 * \pi * N} \\
\text { Output power }=1.73 * \mathrm{~V} * \mathrm{I} * \mathrm{PF}
\end{gathered}
$$

Where,

$\mathrm{T}=$ Torque $(\mathrm{N}-\mathrm{m})$

$\mathrm{N}=$ Speed

$\mathrm{V}=$ Voltmeter value

$\mathrm{I}=$ Ammeter value

$\mathrm{PF}=$ Power Factor $(0.77)$

\section{MATERIALS AND METHODS}

\subsection{Material}

\subsubsection{Aggregates}

Aggregates used in this study are quartzite. 43 grade OPC is used as a filler material. The physical properties are tested in accordance with the IS-2386 and the results are shown in the Table No 1.

\subsubsection{Binder}

VG-30 was used in this work as a binder. The properties are shown in the Table No- 2

Table 1: Physical properties of aggregates

\begin{tabular}{|l|l|l|l|}
\hline $\begin{array}{l}\text { SI. } \\
\text { no }\end{array}$ & Test & $\begin{array}{l}\text { Obtaine } \\
\text { d value }\end{array}$ & $\begin{array}{l}\text { Specifications } \\
\text { as per } \\
\text { MORTH }\end{array}$ \\
\hline 1 & $\begin{array}{l}\text { Aggregate } \\
\text { impact value } \\
\text { test }\end{array}$ & $23.12 \%$ & Max 24\% \\
\hline 2 & $\begin{array}{l}\text { Aggregate } \\
\text { Crushing value } \\
\text { test }\end{array}$ & $26.76 \%$ & Max 30\% \\
\hline 3 & $\begin{array}{l}\text { Los Angeles } \\
\text { abrasion test }\end{array}$ & $26.49 \%$ & Max 30\% \\
\hline 4 & $\begin{array}{l}\text { Water } \\
\text { absorption } \\
20 m m \text { down } \\
12.5 m m \text { down }\end{array}$ & $\begin{array}{l}0.2 \\
0.5\end{array}$ & Max 2\% \\
\hline 5 & $\begin{array}{l}\text { Specific gravity } \\
20 \mathrm{~mm} \text { down } \\
12.5 \mathrm{~mm} \text { down } \\
4.75 \mathrm{~mm} \text { down }\end{array}$ & $\begin{array}{l}2.69 \\
2.66\end{array}$ & - ------- \\
\hline
\end{tabular}

\begin{tabular}{|c|c|c|c|}
\hline $\begin{array}{l}\text { Sl } \\
\text { no }\end{array}$ & Test & Results & $\begin{array}{l}\text { Requirements as } \\
\text { per MORTH }\end{array}$ \\
\hline 1 & $\begin{array}{l}\text { Penetration at } \\
25^{\circ} \mathrm{c}(\mathrm{mm})\end{array}$ & 62 & $50-70$ \\
\hline 2 & $\begin{array}{l}\text { Ductility at } \\
25^{\circ} \mathrm{c}(\mathrm{cm})\end{array}$ & 95 & Min 75 \\
\hline 3 & $\begin{array}{l}\text { Softening } \\
\text { point }\left({ }^{\circ} \mathrm{c}\right)\end{array}$ & 49 & $\operatorname{Min} 47^{\circ} \mathrm{c}$ \\
\hline 4 & $\begin{array}{l}\text { Specific } \\
\text { gravity at } 25^{\circ} \mathrm{c}\end{array}$ & 0.98 & $0.97-1.02$ \\
\hline 5 & $\begin{array}{l}\text { Flash \& Fire } \\
\text { point }\left({ }^{\circ} \mathrm{c}\right)\end{array}$ & $\begin{array}{l}280^{\circ} \mathrm{c} \\
310^{\circ} \mathrm{c}\end{array}$ & $\begin{array}{l}\text { Min } 220^{\circ} \mathrm{c} \\
\text { Min } 270^{\circ} \mathrm{c}\end{array}$ \\
\hline
\end{tabular}

Table 2: Physical Properties of Bitumen

\subsection{Methods}

The methods are parted into three stages to carry out the laboratory investigation. The steps are:

i. Grouping of the aggregates into different percentage of combined flaky and elongation index.

ii. Marshall Method of mix design

iii. Workability of the mix

\subsubsection{Combined Flakiness and Elongation Indices}

On different crushing days, the aggregates were sampled and tested for the combined flakiness and elongation index by using the thickness and length gauge. They are then grouped in to the values as CFEI 30-35\%, CFEI 35-40\%, CFEI $40-45 \%$, CFEI and $45-50 \%$.

\subsubsection{Marshall Method of Mix Design}

The Marshall method of mix design was adopted. This conducted on aggregates of 30-35\%combined flakiness and elongation index of mid gradation. The Optimum Bitumen Content( OBC) was determined at the median air voids for the mid gradation $30-35 \%$ of CFEI. They are shown in the Table No 3.and fig 1 .

\subsubsection{Workability of the Mix}

In the present investigation the workability of the mix for four values of the CFEI at different temperatures were measured by workability testing machine. The instrument is motorized with an RPM of 20. The workability of the mix is measured has torque force at five different temperature range of $140^{\circ} \mathrm{c}, 130^{\circ} \mathrm{c}, 120^{\circ} \mathrm{c}, 110^{\circ} \mathrm{c}, 100^{\circ} \mathrm{c}, 90^{\circ} \mathrm{c}$ and $80^{\circ} \mathrm{c}$. The results are showed in the Table No 4. 


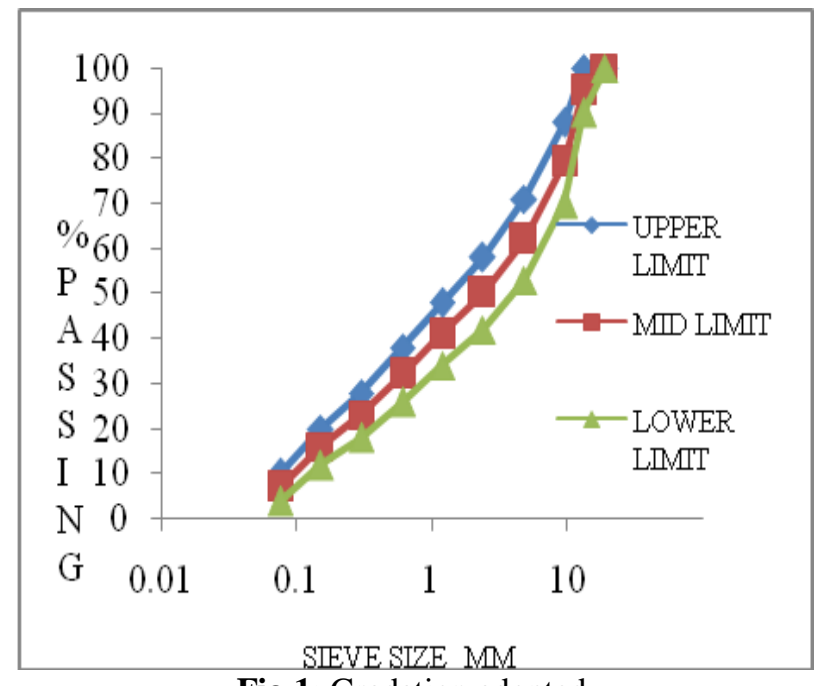

Fig 1: Gradation adopted

Table 3: OBC RESULTS

\begin{tabular}{|l|l|}
\hline Optimum binder content & $5.4 \%$ \\
\hline Per cent air voids (VA) & $4 \%$ \\
\hline Density & $2.37 \mathrm{~g} / \mathrm{cc}$ \\
\hline Stability & $17.2 \mathrm{KN}$ \\
\hline Voids in mineral aggregate per cent (VMA) & 16.3 \\
\hline Per cent voids filled with bitumen (VFB) & 74 \\
\hline Flow mm & 2.9 \\
\hline
\end{tabular}

\section{WORKABILITY RESULTS.}

Table 4: workability results

\begin{tabular}{|c|c|c|c|c|}
\hline CFEI & $\begin{array}{l}\begin{array}{l}\text { Temper } \\
\text { ature }\end{array} \\
\text { Degree }\end{array}$ & $\begin{array}{l}\text { upper } \\
\text { limit } \\
\text { Torque } \\
\text { N-M }\end{array}$ & $\begin{array}{l}\text { middle } \\
\text { limit } \\
\text { Torque } \\
\text { N-M } \\
\end{array}$ & $\begin{array}{l}\text { lower } \\
\text { limit } \\
\text { Torque } \\
\text { N-M }\end{array}$ \\
\hline \multirow{7}{*}{$30-35 \%$} & 140 & 14 & 21.8 & 31.1 \\
\hline & 130 & 20.2 & 28 & 45.1 \\
\hline & 120 & 31.1 & 38.9 & 48.2 \\
\hline & 110 & 38.9 & 45.1 & 60.7 \\
\hline & 100 & 46.7 & 54.4 & 63.8 \\
\hline & 90 & 62.2 & 65.3 & 71.6 \\
\hline & 80 & 79.3 & 82.4 & 91.8 \\
\hline \multirow{8}{*}{$35-40 \%$} & $\begin{array}{l}\text { Temper } \\
\text { ature }\end{array}$ & $\begin{array}{l}\text { upper } \\
\text { limit }\end{array}$ & $\begin{array}{l}\text { middle } \\
\text { limit }\end{array}$ & $\begin{array}{l}\text { lower } \\
\text { limit }\end{array}$ \\
\hline & 140 & 23.3 & 29.6 & 37.3 \\
\hline & 130 & 37.3 & 43.6 & 49.8 \\
\hline & 120 & 48.2 & 51.3 & 59.1 \\
\hline & 110 & 57.6 & 60.7 & 70 \\
\hline & 100 & 70 & 73.1 & 82.4 \\
\hline & 90 & 77.8 & 84 & 93.3 \\
\hline & 80 & 96.4 & 99.6 & 104 \\
\hline & $\begin{array}{l}\text { Temper } \\
\text { ature }\end{array}$ & $\begin{array}{l}\text { upper } \\
\text { limit } \\
\end{array}$ & $\begin{array}{l}\text { middle } \\
\text { limit }\end{array}$ & $\begin{array}{l}\text { lower } \\
\text { limit }\end{array}$ \\
\hline & 140 & 26.4 & 35.8 & 54.4 \\
\hline & 130 & 46.7 & 54.4 & 65.3 \\
\hline
\end{tabular}

\begin{tabular}{|l|l|l|l|l|} 
40-45\% & 120 & 54.4 & 65.3 & 77.8 \\
\cline { 2 - 5 } & 110 & 57.6 & 76.2 & 91.8 \\
\cline { 2 - 5 } & 100 & 76.2 & 93.3 & 109 \\
\cline { 2 - 5 } & 90 & 87.1 & 107 & 134 \\
\cline { 2 - 5 } & 80 & 109 & 121 & 152 \\
\hline \multirow{5}{*}{$\mathbf{4 5 - 5 0 \%}$} & $\begin{array}{l}\text { Temper } \\
\text { ature }\end{array}$ & $\begin{array}{l}\text { upper } \\
\text { limit }\end{array}$ & $\begin{array}{l}\text { middle } \\
\text { limit }\end{array}$ & $\begin{array}{l}\text { lower } \\
\text { limit }\end{array}$ \\
\cline { 2 - 5 } & 140 & 62.2 & 68.4 & 77.8 \\
\cline { 2 - 5 } & 130 & 71.6 & 76.2 & 82.4 \\
\cline { 2 - 5 } & 120 & 77.8 & 80.9 & 91.8 \\
\cline { 2 - 5 } & 110 & 84 & 94.9 & 103 \\
\cline { 2 - 5 } & 100 & 98 & 110 & 121 \\
\cline { 2 - 5 } & 90 & 115 & 129 & 142 \\
\cline { 2 - 5 } & 80 & 126 & 138 & 162 \\
\hline
\end{tabular}

\subsection{Relation between Workability and Temperature} at 30-35\% CFEI.

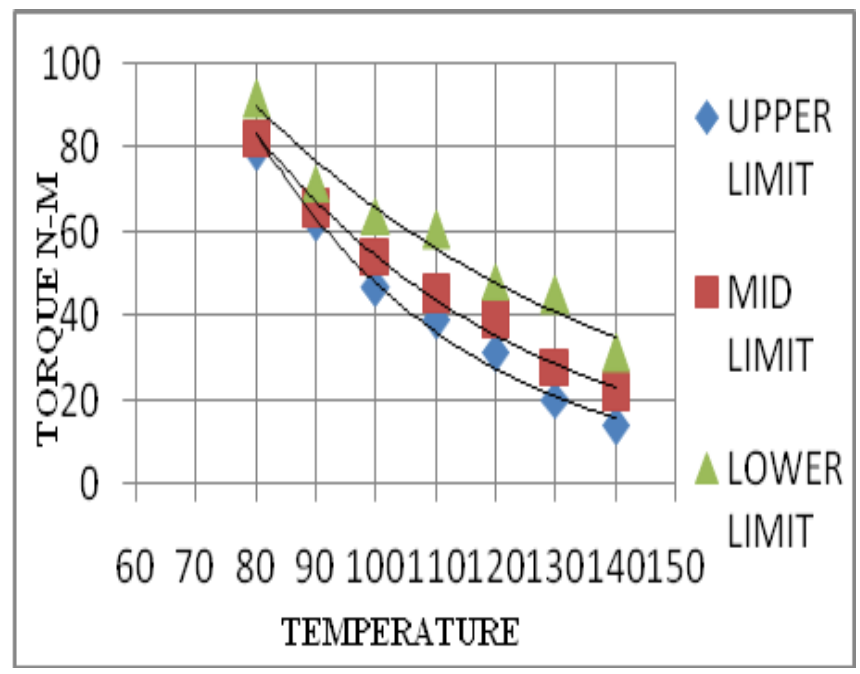

Chart -2: Torque vs Temperature

The Torque is measured to assess the workability of The mix at different temperature. From above graph the torque decreases when increase in the Temperature.30-35\% of CFEI is taken as standard for Analysis of the other increasing $\%$ of combined Indices. In 30-35\% combined indices the torque value lies between 14 to $92 \mathrm{~N}-\mathrm{M}$. 


\subsection{Relation between Workability and Temperature of different \% of CFEI at Upper Limit.}

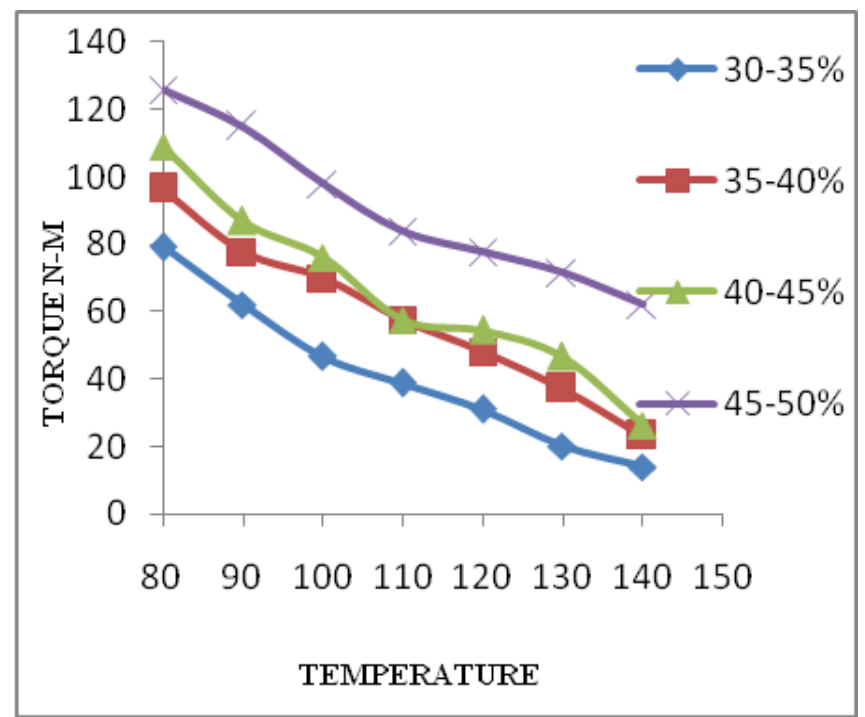

Chart -3: Torque vs Temperature at upper limit

From above graph it is observed that as increasing \% of CFEI the torque value is also increasing. Middle two percentages showing approximately same torque, 30-35\% shows best value compare to other \% at upper limit.

\subsection{Relation between Workability and Temperature} of different \% of CFEI at Middle Limit

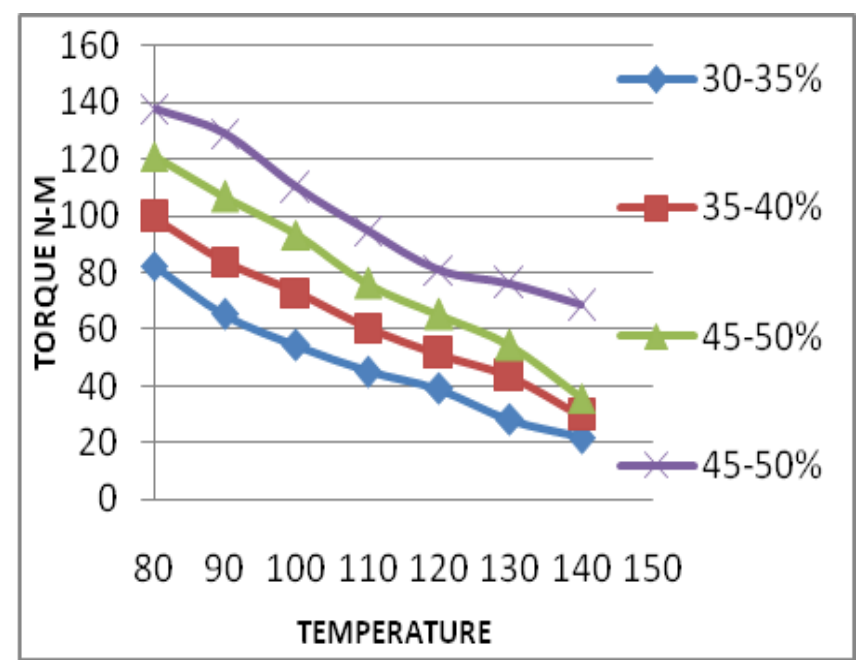

Chart -4: Torque vs Temperature at middle limit

From above graph it is observed that as Increasing percentage of CFEI the torque value is increasing slightly from one $\%$ mid limit to other $\%$.

\subsection{Relation between Workability and Temperature} of different \% of CFEI at Lower Limit.

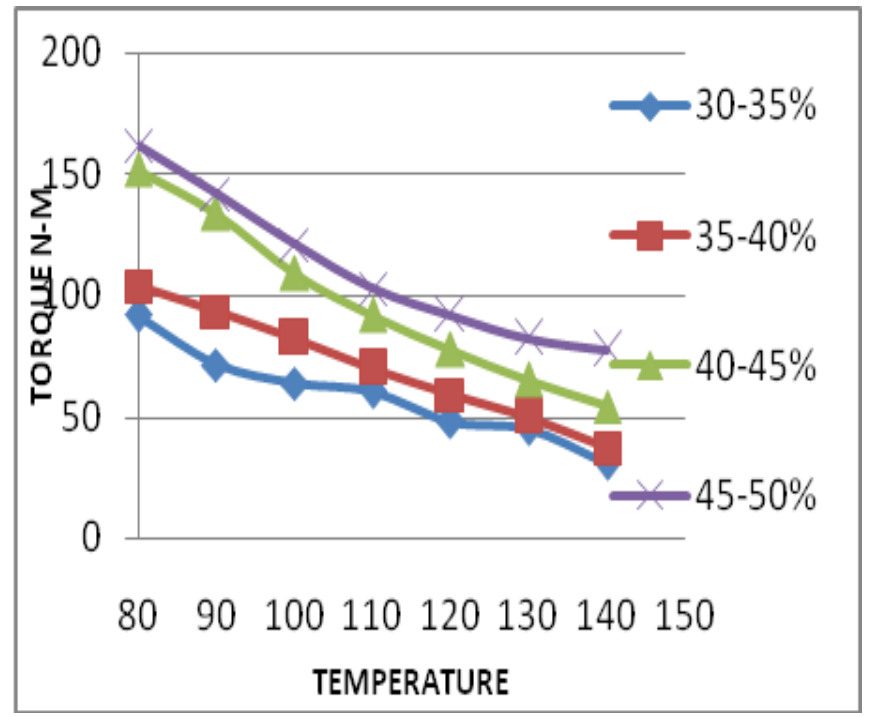

Chart -5: Torque vs Temperature at lower limit

From above graph it is observed that as increasing percentage of CFEI the torque value is increasing from one $\%$ lower limit to other $\%$ lower limit and variation in torque value is very large.

\section{CONCLUSION}

1. The workability measured at different temperatures shows that the mix gets stiffened as the temperature reduces.

2. It is also concluded from this investigation that the workability of the mix gets reduced as the particle shape indices increase.

3. $30-35 \%$ combined indices shows best results at 140 to 110 degree Celsius than other \% of CFEI at upper, middle and lower limits.

\section{ACKNOWLEDGEMENTS}

I would like to thank my guide Mr. K M Mallesh, Associate Professor, HOD \& Staff, Department of Civil Engineering, Siddaganga Institute of Technology, Tumakuru, Karnataka, for their constant encouragement, guidance and support, which enabled me to complete this project.

I would like to thank my parents for their continuous support throughout my life.

\section{REFERENCES}

[1] Ercan Ozgan, Sercan Serin, Tuncay Kap, "Multi faceted investigation into the effects of hot-mix asphalt parameters on Marshall Stability", Construction and Building Materials 40 (2013)419425 
[2] Iuri S. Bessa, Veronica T.F. Castelo Branco, Jorge B.Soares, "Evaluation of different digital image processing software for aggregates and hot mix asphalt characterizations", Construction and Building Materials 37 (2012)370-378

[3] Dong Zhang, Xiaoming Huang, Yongli Zhao, "Investigation of the shape, size, angularity and surface texture properties of coarse aggregates", Construction and Building Materials 34 (2012) 330336

[4] Meor Othman Hamzah, Marliana Azura Ahmad Puzi, Khairun Azizi Mohd Azizli, "Properties of Geometrically cubical aggregates and its Mixture design", IJRRAS 3(3) june 2010

[5] M.N.Bouquety, Y. Descantes, L.Barcelo, F. De Larrard, B.Clavaud, "Experimental study of crushed aggregate shape", Science Direct,ELSEVIER, 21 (2007) 865-872

[6] Chun Wang, Peiwen Hao, Fang Ruan, Xiyan Zhang, Sanjeev Adhikari, "Determination of the production temperature of warm mix asphalt by workability test", ELSEVIER, Construction and Building Materials, 48 (2013) 1165-1170

[7] Salah Mahamed Khalil Abdelgalil, Mohd Yusof Abdul Rahman, and Ahmad Kamil Arshad, "Development of Workability Measuring Device for Asphalt Mixture Using Electronic Transducer and Temperature Regulator", Journal of Basic and Applied Scientific Research, 1(7)721-726, 2011

[8] Bambang Jsmanto Siswosoebrotho, KariantoniGinting, TitiLilianiSoedirdjo, "Workability and Resilient Modulus of Asphalt Concrete Mixtures Containing Flaky Aggregates Shape", Journal of the Eastern Asia Society for Transportation Studies, Vol. 6, pp. 1302-1312, 2005.

\section{BIOGRAPHIES}

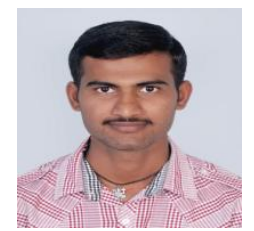

Shivakumara $\mathrm{S}$ N. He is currently studying $\mathrm{M}$ Tech in Transportation Engineering \& Management at Siddaganga Institute of Technology, Tumakuru

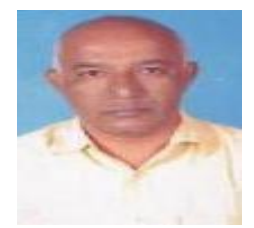

Mallesh K M is currently working as Associate Professor in Siddaganga Institute of Technology in Civil Engineering Department. He is having a more than 25 years experience in the teaching field and also 5years experience in Highway field. He is also senior Material Engineer in KNR Constructions and he is doing Third party Inspection for PMGSY and Suvarna Grama Road projects.

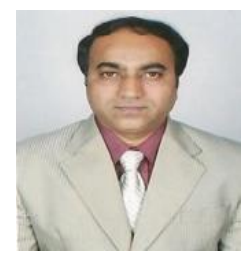

Dr Mohamed Ilyas Anjum is currently working as Vice - Principal \& HoD Civil in Ghousia College of Engineering is having a more than 30 years experience in the teaching field. 